\title{
BEKÖSZÖNTŐ
}

\section{Narratívák hálójában}

Az Információs Társadalom 2003. évi tematikus összeállításai (a gazdasággal és az oktatással foglalkozó számok) magasra tették a mércét a 2004-re tervezett hasonló válogatások („Internet és társadalomtudomány”, „Elektronikus kormányzat”) előtt, ám szerkesztőségünk most egy dupla szám erejéig visszakanyarodik ahhoz az izgalmas sokszínúséghez, ami korábban is jellemezte a lapot.

Az elmúlt időszak alig produkált új diskurzusokat, de érzékelhetően felértékelődött a globalitás mint kontextus: a gazdasági, kulturális és ökológiai szempontok mellett külön foglalkozunk ennek nyelvi vonatkozásaival. (Ld. Nico Stehr és Feketéné Silye Magdolna tanulmányát). Megerôsítve mindazok pozícióját, akik Blaise Galland nyomán „glokálisnak” szeretik nevezni világunkat, érdekesen ellenpontozza ezt a narratívát a vidék távközlési infrastruktúrájának fejles:tésérôl megélénkülő vita. A 2002/4. számban elindított eszmecserét most egy friss amerikai esettanulmány és egy több mint két évtizedes magyar kezdeményezés bemutatásával folytatjuk.

Az információs társadalom történeti dimenziója más formában is megjelenik: a 19. századi „előzményeket” bemutató korábbi tanulmányok (James Beniger és YoAnne Yates) után most Leonard Dudley egyik írását adjuk közre, amelyben ezer éves idősoron mutatja be, milyen sajátos és jól felismerhetô mintázat formájában játszik szerepet az információtechnológia a nagy történelmi változásokban.

Nem tesszük félre a korábbi számainkban rendre visszatéró kognitív szempontok vizsgálatát sem. Matthew Wall-Smith egyéni megközelítése a kognitív aspektust a hálózatiság mind izgalmasabb új generációs fogalmával kapcsolja össze, Tófalvy Tamás recenziója pedig újólag igazolja, hogy még a kognitív etológia is képes hozzájárulni az információs korszak társadalomelméleti megértésének nagy kirakós játszmájához. A tematikus sokszínúség jegyében örömmel adunk helyet két olyan tanulmánynak, amelyek folyóiratunkban eddig még nem érintett kérdéskörökkel foglalkoznak, mindkettő magyar szerzôt dicsér: Sükösd Miklós újszerúen és vitára késztetô módon kapcsolja össze a médiakritikát az ökológiai válsággal, Szabó Gabriella pedig a „nemek” tudománya, a gender studies szemszögéból vizsgálja az információs társadalom jelenségeit. A látszatra egymástól távol esố területeket végül a sajátos nézôpontú Webforradalmár, John Perry Barlow a tôle megszokott provokatív módon kapcsolja össze egyetlen nagyívű gondolatmenetben.

Sok éles vitakérdés, megoldatlan problémák, 'szinoptikus' megközelítések - és mégis, csak töredékek a futó narratívák nagy folyamában. Válogatásaink ennek megfelelően esetlegesek és a szerkesztőség ízlését, trendérzékelését tükrözik. Örömmel fogadnánk olvasóink jelzéseit, javaslatait, írásait, hogy közösen fejleszthessük tovább a lap tematikus profilját.

Z. Karvalics László 